\title{
Ayat-Ayat Waris Dalam Tinjauan Tafsir Maudhu'i dan Penyimpangannya di Indonesia
}

\author{
Windo Putra Wijaya ${ }^{1}$ \\ (Pascasarjana Prodi Ilmu Qur'an dan Tafsir Fakultas Ushuluddin dan \\ Pemikiran Islam UIN RF Palembang) \\ Email: binsyamsuddin87@gmail.com
}

\begin{abstract}
Abstrak: Kajian dengan judul "Ayat-Ayat Waris Dalam Tinjauan Tafsir Maudhu'i dan Penyimpangannya di Indonesia" ini, bertujuan untuk menganalisis pemahaman dan makna dati ayat-ayat waris. Tinjauan tafsir maudhu'i menyoroti bagaimana aplikasi dari pemahaman yang salah khususnya penyimpangan yang banyak terjadi di Indonesia. Dengan menggunakan pendekatan studi pustaka (library reaserch), kajian ini menggunakan dan membandingkan pemikiran para mufassir dan kemudian membenturkan dengan penyimpangan pelaksanaannya di Indonesia. Temuan dari kajian ini adalah pengamalan dan penerapan pembagian waris belum sepenuhnya berdasarkan apa yang dipinta oleh syariat. Tak sedikit penyimpangan-penyimpangan yang terjadi di tengah masyarakat. Penyimpangan tersebut kadangkala tidak hanya berlaku pada masyarakat yang awam terhadap syariat waris, tapi juga dapat berlaku bahkan dikalangan yang semestinya tahu dan paham masalah pembagian waris dalam syariat Islam.
\end{abstract}

Kata kunci: Ayat-ayat waris, tafsir maudhu'i

Abstract: Study with the title "Verses of 'Waris' in the Review of Maudhu'i's Tafsir and Deviations in Indonesia", aims to analyze the understanding and meaning of waris verses. A review of maudhu'i's interpretation highlights how the application of misconceptions, especially perversions that occur in Indonesia. Using a library study approach (library reaserch), this study uses and compares the thoughts of mufassir and then collides with the deviation of their implementation in Indonesia. The findings of this study are that the practice and application of inheritance is not entirely based on what is requested by the Shari'a. Not a few deviations that occur in the community. These deviations sometimes not only apply to people who are unfamiliar with the law of inheritance, but can also apply even among those who should know and understand the problem of the distribution of inheritance in Islamic law.

Keywords: The verses of waris, tafsir Maudhu'i 


\section{Pendahuluan}

Islam adalah agama yang sempurna. Agama yang menjadi tuntunan diseluruh lini kehidupan makhluk ciptaan Allah Swt. Tidak ada satupun yang luput dari petunjuk-Nya. Adanya tuntunan tersebut, tentu untuk kemaslahatan makhluk itu sendiri. Tidaklah ada satu perintah ataupun larangan yang datang dari-Nya, kecuali bernilai kebaikan untuk urusan dunia dan akhirat. ${ }^{1}$

Diantara tujuan adanya tuntunan dalam agama ini adalah menjaga kepemelikan harta seseorang. Islam sangat melarang keras terjadinya perpindahan harta dari satu orang ke orang yang lain dengan cara yang batil. Karena itu, merampok, mencuri, korupsi atau merampas harta orang lain dengan cara yang tidak benar sangat dikecam dalam Islam.

Dalam hidup, perpindahan harta dari satu orang ke orang lain yang tak dapat dielakkan adalah ketika seseorang meninggal dunia. Kepemilikan harta dari orang yang meninggal atau yang disebut dengan pewaris akan berpindah kepada orang-orang terdekat yang berhak menerimanya atau disebut ahli waris. Harta yang akan beralih pemiliknya ini disebut harta waris atau warisan. Harta waris ini dibagikan kepada yang berhak menerimanya sesuai dengan ketentuan yang sudah diatur dalam syariat. Ilmu pembagian harta waris ini dikenal dengan ilmu waris atau ilmu faraidh.

Ilmu waris memiliki kedudukan yang istimewa dalam syariat. Mempelajarinya adalah fardhu kifayah (wajib perwakilan), tapi pengamalan atau mempraktikkan pembagian waris menurut syariat menjadi fardhu 'ain (wajib individu). Syariat Islam menetapkan aturan waris dengan bentuk yang sangat teratur dan adil. Al-Qur'an menjelaskan dan merinci secara detail hukum-hukum yang berkaitan dengan hak kewarisan tanpa mengabaikan hak seorang pun. Bagian yang harus diterima semuanya dijelaskan sesuai kedudukan nasab

\footnotetext{
${ }^{1}$ Razzaq, A., \& Haryono, A. (2017). Analisis Metode Tafsir Muhammad Ash-Shabuni dalam Kitab rawâiu' al-Bayân. Wardah, 18(1), https://doi.org/https://doi.org/10.19109/wardah.v18i1.1432
} 
terhadap pewaris, apakah dia sebagai anak, ayah, istri, suami, kakek, ibu, paman, cucu, atau bahkan hanya sebatas saudara seayah atau seibu. ${ }^{2}$

Kata waris berasal dari bahasa Arab yang diambil dari kata 'warits \ayarits $\backslash$-wirts \an', isim failnya waritsun yang artinya ahli waris. ${ }^{3}$ Adapun makna waris menurut bahasa ialah berpindahnya sesuatu dari seseorang kepada orang lain. Atau dari suatu kaum kepada kaum lain. ${ }^{4}$ Kata waris terdapat dalam berbagai bentuk, makna tersebut dapat kita temukan dalam al-Qur'an, antara lain: ${ }^{5}$

a. Mengandung makna "mengganti kedudukan" (QS. al-Naml, 27:16)

b. Mengandung makna "memberi atau menganugerahkan" (QS. al-Zumar, 39:74)

c. Mengandung makna "mewarisi atau meminta warisan" (QS. Maryam, 19:6)

Dalam literatur fiqih Islam, kewarisan lazim juga disebut dengan faraidh, yaitu jamak dari kata faridhah diambil dari kata fardh yang bermakna ketentuan atau takdir. Al-fardh dalam terminologi syar'i ialah bagian yang telah ditentukan untuk ahli waris. ${ }^{6}$

Adapun dalam istilah umum, waris adalah perpindahan hak kebendaan dari orang yang meninggal dunia kepada ahli waris yang masih hidup. Pengertian, tersebut sejalan dengan apa yang disampaikan oleh Wiryono Projodikoro, bahwa definisi waris adalah soal apakah dan bagaimanakah hak-hak dan kewajibankewajiban tentang kekayaan seseorang pada waktu ia meninggal akan beralih kepada orang lain yang masih hidup. ${ }^{7}$

${ }^{2}$ Muhammad Ali al-Shabuni, Pembagian Waris Menurut Islam, ter. A.M Basalamah Jakarta: Gema Insani Press, 1996, hlm.33

${ }^{3}$ Mahmud Yunus, Kamus Arab-Indonesia, Jakarta: Hidakarya Agung, 1990, Cet Ket-8, hlm. 496

${ }^{4}$ Mahmud Yunus, Kamus Arab..., hlm. 496

${ }^{5}$ Ahmad Rofiq, Hukum Islam di Indonesia, Jakarta: PT. Raja Grafindo Persada, 2000, Cet. Ke-4, 2000, hlm. 355

${ }^{6}$ Muhammad Amin Summa, Hukum Keluarga Islam di Dunia Islam, Jakarta; PT. Raja Grafindo Persada, 2005, hlm. 109

7 Wiryono Projodikoro, Hukum Warisan di Indonesia, Bandung: Sumur, 1983, hlm. 13

7 Al-Shabuni, Pembagian Waris..., hlm. 34 
Sedangkan makna al-mirats menurut istilah yang dikenal para ulama ialah berpindahnya hak kepemilikan dari orang yang meninggal kepada ahli warisnya yang masih hidup, baik yang ditinggalkan itu berupa harta (uang), tanah, atau apa saja yang berupa hak milik legal secara syar'i. ${ }^{7}$

Dari pemahaman ini, secara garis besar definisi warisan yaitu perpindahan berbagai hak dan kewajiban tentang kekayaan seseorang yang meninggal dunia kepada orang lain yang masih hidup dengan memenuhi syarat dan rukun dalam mewarisi.

\section{Tahap-Tahap Perkembangan Pewarisan Islam}

Di antara tujuan utama adanya sistem kewarisan Islam adalah untuk mengoreksi sistem kewarisan yang tidak adil yang sudah berlaku sejak pada masamasa pra-Islam. Sebagaimana sistem hukum pada umumnya yang berkembang melalui tahapan-tahapan historis tertentu, maka demikian juga halnya dengan sistem kewarisan Islam. keputusan-keputusan mendetail tentang kewarisan Islam, baik berupa wahyu maupun sunnah Nabi Muh\}ammad saw., berjalan secara regular dan berangsur-angsur selama 22 tahun dalam periode antara permulaan dakwah Nabi Muh \}ammad pada tahun 610 sampai wafat beliau pada tahun $632 \mathrm{M}$.

Secara kronologis, perkembangan sistem kewarisan Islam dapat dikelompokkan de dalam tiga tahap perkembangan, yaitu:

\section{Tahap Pertama: Pewahyuan Ayat-ayat Wasiat}

Setidaknya pada tahap awal ini terdapat enam ayat yang diwahyukan kepada Nabi Muhammad saw., yang isinya mengatur tentang kewarisan melalui mekanisme wasiat. Yaitu QS. al-Baqarah [2]: 180-182, dan 240, dan QS. alMa'idah [5]: 105-106. ${ }^{8}$

QS. al-Baqarah [2] ayat 180 memerintahkan kepada orang yang akan meninggal dunia untuk membuat wasist kepada orang tua dan sanak kerabat; ayat 181 menjelaskan tentang pertanggung-jawaban dosa bagi orang yang mengubah

8 Abu al-Qasim Mahmud bin Umar bin Muhammad al-Zamakhsyari, al-Kasysyaf 'an Haqaiq Ghawamidh al-Tanzil wa 'Uyun al-Aqawil fi Wujuh al-Ta'wil, Beirut: Dar al-Kutub al'Ilmiyyah, 1995, hlm. 289 
isi wasiat; ayat 182 menjelaskan tentang kemungkinan untuk mengubah atau membatalkan isi wasiat jika pewasiat melakukan kesalahan atau berbuat dosa dalam wasiatnya; dan ayat 240 memerintahkan agar orang yang meninggal dunia berwasiat untuk jandanya agar ia diberi nafkah selama setahun dan membiarkannya untuk tinggal di rumah almarhum suaminya selama periode tersebut; sementara QS. al-Ma'idah [5]: 106-107 menjelaskan bahwa wasiat harus dibuat di hadapan dua orang saksi yang terpercaya.

Keenam ayat di atas, merefleksikan suatu aturan hukum yang memberikan kebebasan secara luas kepada seseorang untuk siapa-siapa yang akan menjadi ahli warisnya dan berapa banyak bagian yang akan diberikan kepada mereka masingmasing.

\section{Tahap Kedua: Pewahyuan Ayat-ayat Waris}

Sejarah Islam menggambarkan bahwa dalam tahap kedua ini, karakter hukum pewarisan bersifat ketat dan pasti sebagaimana tercermin dalam ayat-ayat waris yang diwahyukan pada masa ini, dan sekaligus ia menggantikan sistem pembagian harta tinggalan melalui sistem wasiat yang diwahyukan pada tahap pertama yang bersifat permisif dan leluasa.

Dalam sebuah riwayat asbab al-nuzul diriwayatkan bahwa Ummu Kuhha mengadu kepada Nabi Muhammad perihal harta peninggalan suaminya yang diammbil seluruhnya oleh sepupu almarhum suaminya, dan tidak meninggalkan sedikitpun untuk dirinya dan kedua putri almarhum. Dalam kaitannya ini, menurut riwayat asbab al-nuzul, Allah memberikan tanggapan-Nya dalam dua tahap, dimulai dengan pewahyuan QS. al-Nisa' [4]: 8 yang menegaskan hak para wanita untuk mewarisi dan sekaligus untuk membatalkan praktek pewarisan pada zaman jahiliyyah, dan sesaat kemudian diikuti dengan pewahyuan QS. al- Nisa' [4]: 1112, yang merinci secara jelas bagian-bagian waris bagi para ahli waris. ${ }^{9}$ Kemudian dua ayat terakhir di atas (QS. al-Nisa' [4]: 11-12) bersama dengan QS. al-Nisa' [4]: 176, yang menjelaskan tentang bagian-bagian warisan untuk saudarasaudara seayah dan sekandung, menjadi inti dari ilmu faraidh.

\footnotetext{
${ }^{9}$ Ali bin Ahmad al-Wahidi, Asbab Nuzul al-Quran, Kairo: Dar al-Kitab al-Jadid, 1969,
} hlm. 137 
Perbedaan antara dua pewahyuan di atas sangatlah jelas. Pada pewahyuan pertama di Madinah (ayat-ayat wasiat), pewasiat sendiri yang menetapkan jenis dan pembagian kepada ahli waris yang ia tunjuk; sementara pada pewahyuan ke dua Allah sendirilah yang menentukan siapa saja yang berhak mendapatkan warisan dan berapa besar prosentase harta warisan yang berhak mereka terima masing-masing.

\section{Tahap Ketiga: Penjelasan Sunnah Nabi}

Meskipun para ulama Islam menggambarkan bahwa pembentukan ilmu Fara 'idh adalah sebagai suatu proses akhir dari sistem sukarela yang dicerminkan dalam ayat-ayat wasiat menjadi aturan-aturan wajib yang ditentukan dalam ayatayat waris sebagaimana nampak dalam dua serial pewahyuan di atas melalui doktrin naskh, nampaknya persoalan pewarisan belumlah jelas dan masih membutuhkan penjelasan lebih lanjut. Hal ini mengingat, QS. Al-Baqarah [2]: 1112, yang menjelaskan tentang bagian-bagian (furudh) waris bagi ahli waris, masih mensyaratkan bahwa pembagian harta warisan tersebut harus dilakukan setelah ditunaikanya wasiat atau hutang dari almarhum; yang dengan itu menunjukkan bahwa wasiat belum sepenuhnya dihapus. Pertanyaan terhadap siapa sajakah wasiat masih boleh diberlakukan, menurut para ulama, dijawab oleh sunnah Nabi Muhammad yang menetapkan dua pembatasan utama tentang pemberlakuan wasiat. ${ }^{1011}$

Pembatasan pertama, tentang kadar maksimal yang boleh diwasiatkan, yakni hanya sepertiga dari harta peninggalan, sementara dua sepertiga dari harta peninggalan harus dibagikan kepada ahli waris berdasarkan syari'at yang ditawarkan dalam ayat-ayat waris. Menurut riwayat, pembatasan pertama disampaikan oleh Nabi Muhammad segera sesudah penaklukan kota Makkah (fathu Makkah) pada tahun 630 Masehi, ketika Nabi menjenguk salah seorang sahabat, Sa'ad bin Abi> Waqqash yang sedang sakit dan merasa bahwa ia akan meninggal dunia lantaran sakitnya tersebut, maka kemudian ia bertanya kepada

${ }^{10}$ Wahbah al-Zuhaily, al-Fiqh al-Islam wa Adillatuh, Beirut: Dar al-Fikr, 1997, hlm.

${ }^{11}$ Razzaq, A., \& Saputra, D. (2016). Studi Analisis Komparatif Antara Ta'wil dan Hermeneutika dalam Penafsiran al-Qur'an. Wardah,17(2), 89-114. Retrieved from http://jurnal.radenfatah.ac.id/index.php/warda/article/view/961. 
Nabi Muhammad: apakah ia boleh mewasiatkan seluruh hartanya? Nabi saw. melarangnya dan menjelaskan ia hanya boleh mewasiatkan sepertiga dari hartanya. ${ }^{12}$ Pada akhirnya, pembatasan tersebut dapat dipahami oleh mayoritas ulama sebagai upaya untuk menemukan keseimbangan antara aspek sukarela dan aspek wajib dalam hukum waris.

Pembatasan kedua adalah sabda Nabi Muhammad saw.: "tidak ada wasiat terhadap ahli waris", yang menurut riwayat, disampaikan oleh Nabi saw. dalam kesempatan haji wada' pada tahun 632 Masehi. Pembatasan tersebut adalah untuk menghilangkan adanya ketumpang-tindihan adanya ayat-ayat wasiat dan ayat-ayat waris tentang penunjukan ahli waris yang sama dalam hal pewarisan. Sehingga, melalui sabda Nabi Muhammad saw. tersebut para ulama berkesimpulam bahwa wasiat tidak boleh diberikan kepada siapapun yang telah ditetapkan sebagai "ahli waris", yaitu siapa saja yang telah diberikan bagian pasti warisan. Terlebih, menurut sebagian ulama, QS. Al-Baqarah [2]: 180 yang menjelaskan kewajiban untuk meninggalkan wasiat kepada ibu-bapak dan sanak kerabat, dan ayat 240 tentang wasiat kepada istri, telah dihapus oleh QS. Al-Nisa' [4]: 11-12 yang berisi tentang uraian pembagian waris. ${ }^{36}$

\section{Penafsiran Ulama Terhadap Teks Waris}

Menurut hemat penulis, ayat al-Qur'an yang membahas tentang waris (pembagian warisan yang pasti) adalah QS. Al-Nisa' (4): 11, 12 dan 176.

Dan penafsiran ulama mengenai ayat tersebut akan dipaparkan di bawah ini:

1. Q.S. Al-Nisa>' (4): 11

Allah mensyari'atkan bagimu tentang (pembagian pusaka untuk) anak-anakmu. Yaitu : bahagian seorang anak lelaki sama dengan bagian dua orang anak perempuan; dan jika anak itu semuanya perempuan lebih dari dua, maka bagi mereka dua pertiga dari harta yang ditinggalkan; jika anak perempuan itu seorang saja, maka ia memperoleh separo harta. Dan untuk dua orang ibu-bapa, bagi masing-masingnya seperenam dari harta yang ditinggalkan,

12 Abu Abdillah Muhammad bin Ismail al-Bukhari, al-Jami' al-Shahih: Kairo: Dar alHadits, 2004, Jilid 2, hlm. 26 
jika yang meninggal itu mempunyai anak; jika orang yang meninggal tidak mempunyai anak dan ia diwarisi oleh ibubapanya (saja), maka ibunya mendapat sepertiga; jika yang meninggal itu mempunyai beberapa saudara, maka ibunya mendapat seperenam. (Pembagian-pembagian tersebut di atas) sesudah dipenuhi wasiat yang ia buat atau (dan) sesudah dibayar hutangnya. (Tentang) orang tuamu dan anak-anakmu, kamu tidak mengetahui siapa di antara mereka yang lebih dekat (banyak) manfaatnya bagimu. Ini adalah ketetapan dari Allah.

Sesungguhnya Allah Maha Mengetahui lagi Maha Bijaksana.

Dalam tafsir al-Baidawi, yang berjudul Anwar al-Tanzil wa Asraru alTa'wil menjelaskan bahwa Allah memerintah dan mengamanahkan kepadamu perihal pembagian satu orang laki-laki sama dengan dua orang perempuan, beserta kelipatannya. Artinya jika terdapat dua orang laki-laki berarti bagiannya sama dengan empat orang perempuan. Anak laki-laki memiliki kekhususan mendapatkan bagian lebih banyak daripada perempuan dengan tujuan untuk menunjukkan bahwa laki-laki memiliki keutamaan. Dan bagian anak laki-laki yang melebihi anak perempuan dianggap cukup untuk menunjukkan bahwa lakilaki memiliki keutamaan dibanding perempuan. ${ }^{13}$ Bagian dua banding satu untuk anak laki-laki merupakan pembagian harta warisan yang telah disyari'atkan dalam oleh Allah yang telah tercantum dalam al-Qur'an.

Allah memerintahkan kalian untuk berlaku adil terhadap anak-anak mereka. Karena dahulu orang-orang Jahiliyah memberikan semua harta pusaka hanya untuk ahli waris laki-laki saja. Sedangkan ahli waris perempuan tidak mendapatkan sesuatu apapun dari harta peninggalan. Maka Allah memerintahkan untuk berlaku adil kepada mereka (para ahli waris) dalam membagi harta warisan. Akan tetapi bagian kedua jenis dibedakan oleh Allah; Dia menjadikan bagian lakilaki sama dengan dua perempuan. Dengan alasan seorang laki-laki dituntut kewajiban memberi nafkah, beban biaya lainnya, jerih payah dalam berniaga, dan beruhasa serta menanggung semua hal yang berat. Maka sudah menjadi harga

${ }^{13}$ Nashiruddin Abu Sa'id Abdullah al-Baidhawi, Anwar al-Tanzil wa Asraru al-Ta'wil, Beirut: Dar Ihya al-Turats al-'Arabi, 1418 H, Juz II, hlm. 62 
yang pantas jika laki-laki diberi bagian dua kali lipat dari bagian yang diterima perempuan. ${ }^{14}$

Ketika turun ayat tersebut maka orang-orang merasa tidak suka atau sebagian dari mereka tidak senang dengan pembagian itu. Di antara mereka ada yang mengatakan, "wanita diberi seperempat atau seperdelapan dan anak perempuan diberi setengah serta anak laki-laki kecil pun diberi, padahal tiada salah seorang pun dari mereka yang berperang membela kaumnya dan tidak dapat merebut ghanimah.” Akan tetapi hadis ini didiamkan saja; barang kali Rasulullah melupakannya, atau kita katakan kepadanya, lalu beliau bersedia mengubahnya. Mereka berkata, "Wahai Rasulullah, mengapa engkau memberikan harta warisan kepada anak perempuan setengah dari harta yang ditinggalkan ayahnya, padahal ia tidak menaiki kuda dan tidak pula berperang membela kaumnya?" bahkan anak kecil pun diberi bagian warisan, padahal ia tidak dapat berbuat apa-apa. ${ }^{15}$

Diketahuilah bahwa pada masa Jahiliyah mereka tidak memberikan warisan kecuali hanya pada orang yang berperang membela kaumnya. Dan mereka hanya memberikannya kepada anak yang tertua dan yang lebih tua lagi.

Demikianlah menurut riwayat Ibnu Abi Hatim dan Ibnu Jarir. ${ }^{16}$

Dari kedua penafsiran tersebut dapat ditarik kesimpulan bahwa bagian laki-laki adalah dua kali lipat dari bagian perempuan terhadap harta peninggalan. Akan tetapi alasan dari besarnya bagian antara laki- laki dan perempuan berbeda. Al-Baidhawi berpendapat bahwa bagian laki-laki lebih besar dari perempuan karena laki-laki lebih memiliki keutamaan daripada perempuan. Sedangkan menurut Ibnu Katsir, laki- laki mendapat bagian lebih besar karena seorang lakilaki dituntut kewajiban memberi nafkah, beban biaya lainya, jerih payah dalam berniaga, dan berusaha serta menanggung semua hal yang berat.

Dan alasan yang kedua ini sama dengan pendapatnya Ali Ahmad alJurjawi. ${ }^{17}$

\footnotetext{
${ }^{14}$ Ibn Katsir, Tafsir al-Quran al-Azhim, Kairo: Dar al-Hadits, 2010, Juz II, hlm. 223

${ }^{15} \mathrm{Ibn}$ Katsir, Tafsir al-Quran, hlm. 224

${ }^{16}$ Ibn Katsir, Tafsir al-Quran, hlm. 224

${ }^{17}$ Ali Ahmad Al-Jurjawi, Hikmah al-Tasyri' wa Falsafatuhu, Beirut: Dar al-Fikr, 2003,
} hlm. 270 
2. Q.S. Al-Nisa' (4): 12

Dan bagimu (suami-suami) seperdua dari harta yang ditinggalkan oleh isteri-isterimu, jika mereka tidak mempunyai anak. jika isteriisterimu itu mempunyai anak, Maka kamu mendapat seperempat dari harta yang ditinggalkannya sesudah dipenuhi wasiat yang mereka buat atau (dan) sesudah dibayar hutangnya. Para isteri memperoleh seperempat harta yang kamu tinggalkan jika kamu tidak mempunyai anak. jika kamu mempunyai anak, Maka Para isteri memperoleh seperdelapan dari harta yang kamu tinggalkan sesudah dipenuhi wasiat yang kamu buat atau (dan) sesudah dibayar hutang-hutangmu. Jika seseorang mati, baik laki-laki maupun perempuan yang tidak meninggalkan ayah dan tidak meninggalkan anak, tetapi mempunyai seorang saudara laki-laki (seibu saja) atau seorang saudara perempuan (seibu saja), Maka bagi masing-masing dari kedua jenis saudara itu seperenam harta. tetapi jika saudarasaudara seibu itu lebih dari seorang, Maka mereka bersekutu dalam yang sepertiga itu, sesudah dipenuhi wasiat yang dibuat olehnya atau sesudah dibayar hutangnya dengan tidak memberi mudharat (kepada ahli waris). (Allah menetapkan yang demikian itu sebagai) syari'at yang benar-benar dari Allah, dan Allah Maha mengetahui lagi Maha Penyantun.

Pada ayat ini diuraikan al-furudh al-muqaddarah bagi suami dan istri. Dengan kata lain ayat ini menguraikan hak waris yang melekat pada seseorang yang disebabkan adanya ikatan pernikahan. Selain itu pada ayat ini juga diuraikan bagian dari orang yang berstatus kalalah. Suami berhak mendapatkan seperdua dari harta yang ditinggalkan oleh istri (baca: tirkah) jika memang istri yang meninggal tersebut tidak mempunyai anak. Sedangkan jika sang istri yang meninggal tersebut memiliki anak, maka bagian suami tersebut menjadi seperempat dari tirkah. Dengan kata lain nominal setengah harta tirkah yang menjadi hak suami terkurangi dengan keberadaan anak yang ditinggalkan oleh sang istri.

Sedangkan istri yang ditinggal mati suaminya medapatkan seperempat harta yang ditinggalkannya (baca: tirkah). Seperempat tirkah ini didapatkannya dengan syarat si suami tidak meninggalkan anak. Namun jika meninggalkan anak, 
maka istri mendapatkan seperdelapan dari tirkah suami. Keberadaan anak sebagaimana dalam furudh istri juga menjadi pengurang dari bagian awal (seperempat tirkah) yang berhak mereka terima sama seperti dalam kasus waris suami di atas. Dengan kata lain keberadaan anak menjadi hijab nuqshan bagi bagian waris dari suami dan istri. ${ }^{18}$

Nominal tersebut baru dapat diakses baik oleh suami ataupun istri setelah menunaikan urusan wasiat dan membayar hutang jika memang ada. Dua hal ini secara normatif harus terlebih dahulu diselesaikan agar nanti pada saat pembagian warisan dapat berjalan secara prosedural dan lancar dalam realitanya. Lebih detail lagi disebutkan dalam kajian fikih bahwa pembagian waris dapat dilakukan setelah terselesaikannya setidaknya empat hal. Pertama menyelesaikan hal yang berkaitan dengan keberadaan harta tirkah seperti zakat, gadai bahkan urusan pidana. Kedua, pembiayaan perawatan jenazah, ketiga penyelesaian dan pelunasan hutang, keempat melaksanakan wasiat dari mayit. ${ }^{19}$

Setelah memaparkan hak waris bagi suami dan istri selanjutnya ayat di atas menggambarkan bagian dari seseorang yang bersifat kalalah. Kalalah dalam bahasa Indonesia diterjemahkan sebagai seseorang yang mati yang tidak mempunyai ayah dan anak. Bagi seorang yang kalalah namun memiliki seorang saudara laki-laki (seibu saja) atau seorang saudara perempuan (seibu saja), maka bagi masing- masing dari kedua jenis saudara itu seperenam harta. Namun jika saudara-saudara seibu itu lebih dari seorang, maka mereka bersekutu dalam yang sepertiga bagian tersebut.

Ayat di atas memuat banyak redaksi yang dalam disiplin ilmu nahwu disebut sebagai isim nakirah. Isim nakirah secara sederhana didefinisikan sebagai sebuah kata benda yang memiliki makna namun masih bersifat umum atau belum tertentu dan belum terbatasi. ${ }^{2021}$ Mari perhatikan kata waladun, akhun dan ukhtun yang ketiganya dalam bentuk nakirah. Keadaan ini tentu akan mempengaruhi

${ }^{18}$ Sulaiman bin Muhammad bin Umar al-Bujairimi, Tuhfah al-Habib 'ala Syarh alKhatib, Beirut: Dar al-Fikr, Tanpa Tahun, Juz 3, hlm. 313

${ }^{19}$ Usman bin Syata al-Dimyathi, I'anah al-Thalibin 'ala Hilli Alfazhi Fath al-Mu'in, Beirut: Dar al-Fikr, 1997, Juz 3, hlm. 261

${ }^{20}$ Abu al-Baqa' al-Ukburi, al-Lubab fi 'Ilal al-Bina wa al-I'rab, Damaskus: Dar al-Fikr, ${ }^{21}$, Juz 1, hlm. 471 
dalam pemaknaan. Kata walad, akhun dan ukhtun memiliki makna yang masih umum dan cenderung luas. Kata walad yang dalam bahasa Indonesia diterjemahkan dengan kata "anak" muhtamil kepada anak dari hasil pernikahan dengan suami (terkini) ataupun anak dari seseorang yang pernah menjadi suami dari istri tersebut. Begitu pula kata akhun dan ukhtun yang dinarasikan dalam bentuk nakirah juga muhtamil kepada akhun atau ukhtun syaqiq, akhun atau ukhtun lil umm ataupun akhun akhun atau ukhtun lil abb. Analisa redaksional sebagaimana yang diungkapkan penulis di atas diperkuat dengan pernyataan alShobuni $^{22}$, Sayyid Quthb ${ }^{23}$ dan Sayyid Tanthowi ${ }^{24}$ dalam masing-masing tafsir mereka.

\section{Q.s. Al-Nisa' (4): 176}

Mereka meminta fatwa kepadamu (tentang kalalah). Katakanlah: "Allah memberi fatwa kepadamu tentang kalalah (yaitu): jika seorang meninggal dunia, dan ia tidak mempunyai anak namun mempunyai saudara perempuan, Maka bagi saudara perempuannya itu seperdua dari harta yang ditinggalkannya. Dan saudaranya yang laki-laki mempusakai (seluruh harta saudara perempuan), jika ia tidak mempunyai anak; namun jika saudara perempuan itu dua orang, maka bagi keduanya dua pertiga dari harta yang ditinggalkan oleh yang mayit. Dan jika mereka (ahli waris itu terdiri dari) saudara-saudara laki dan perempuan maka bagian seorang saudara laki-laki sebanyak bagian dua orang saudara perempuan. Allah menerangkan (hukum ini) kepadamu, supaya kamu tidak sesat. dan Allah Maha mengetahui segala sesuatu.

Ayat di atas diturunkan sebagai jawaban atas kegundahan Jabir bin Abdullah. Pada saat itu Jabir yang mengalami sakit keras dan hidup sebagai seorang kalalah dengan sembilan saudari nya bertanya kepada Rasul SAW perihal

\footnotetext{
${ }^{22}$ Muhammad Ali Al-Shabuni, Shafwah al-Tafsir, Kairo: Dar al-Shabuni, 1997, Juz 1,
} hlm. 241

${ }^{23}$ Sayyid Quthb, Fi Zhilal al-Quran, Kairo: Dar al-Syuruq, 1991, Juz 1, hlm. 593

${ }^{24}$ Muhammad Sayyid Thantawi, al-Tafsir al-Wasith, Kairo: Dar Nahdhah, 1997, Juz 3, hlm. 72 
bagaimana mengelola hartanya jika nantinya dia mati. ${ }^{25}$ Sahabat Jabir disebut kalalah karena dia; seandainya meninggal nantinya tidak memiliki ahli waris selain saudari-saudarinya tersebut. Dia tidak memiliki anak dan ayah yang masih hidup pada saat itu. Jadi secara definitif kata kalalah diartikan dengan seseorang yang tidak memiliki (tidak meninggalkan; ketika mati nanti) anak dan orang tua. ${ }^{26}$ Definisi tersebut sebenarnya memiliki esensi yang sama dengan yang dinarasikan dalam ayat di atas. Bagi yang berkondisi kalalah maka saudara yang dipunyai-lah yang menjadi ahli waris dari si mayyit tersebut.

Adapun nominal dari bagian mereka (saudari perempuan; baik sebapak atau sekandung) adalah setengah dari harta. Jika saudari perempuan tersebut tidak memiliki anak, maka bagi saudara laki-laki; baik sebapak atau sekandung berhak mendapatkan sebagian dari tirkah. Jika saudara perempuan tersebut berjumlah dua maka bagi mereka (berdua) dua pertiga dari tirkah. Dengan kata lain bilangan nominal dua pertiga dari tirkah tersebut dibagi dua sehingga masing-masing mendapatkan satu pertiga dari tirkah. Nominal tersebut berhak didapatkan para ahli waris jika telah terselesaikannya wasiat dan lunasnya hutang. Hal ini memang secara eksplisit tidak ada dalam ayat di atas, namun penulis mengkiaskannya dengan kedua ayat yang ada sebelumnya yang mensyaratkan kedua hal tersebut (lihat dalam QS. Al- Nisa` (4): 12 dan QS. Al-Nisa` (4): 11).

\section{Realitas Pewarisan di Indonesia dan Kendalanya}

Hari ini, realita di Indonesia, pengamalan dan penerapan pembagian waris belum sepenuhnya berdasarkan apa yang dipinta oleh syariat. Tak sedikit penyimpangan-penyimpangan yang terjadi di tengah masyarakat. Penyimpangan tersebut kadangkala tidak hanya berlaku pada masyarakat yang awam terhadap syariat waris, tapi juga dapat berlaku bahkan dikalangan yang semestinya tahu dan paham masalah pembagian waris dalam syariat Islam.

Beberapa kasus penyimpangan yang terjadi di Indonesia diantaranya:

25 Faishal bin Abdul Aziz, Taufiq al-Rahman fi Durus al-Quran, Riyadh: Dar al'Ashimah: 1996, Juz 2, hlm. 22

${ }^{26}$ Muhammad bin Muhammad bin Abd al-Razzaq al-Husaini , Taj al-'Urus min Jawahir al-Qamus, tanpa penerbit, Dar al-Hidayah, Tanpa Tahun, Juz 30, hlm. 344 
1. Menunda pembagian harta warisan.

2. Usaha untuk membagi rata pembagian waris antara anak laki-laki dengan anak perempuan.

3. Membagi waris berdasarkan kesepakatan.

4. Adanya pemahaman tentang kemestian menjual dengan cepat aset-aset warisan yang ada.

5. Tercampurnya harta suami dan istri

6. Kekeliruan dalam membedakan hibah, wasiat dan waris.

Pada kasus pertama ketika menunda pembagian harta warisan, seringkali terjadi bila diantara ahli waris adalah pasangan (suami/istri) dari orang yang meninggal. Sehingga harta warisan dipegang penuh oleh ahli waris pasangan yang meninggal. Perkara ini kalau dibiarkan, akan menjadi bom waktu yang akan meledak pada waktunya. Penundaan pembagian harta warisan akan menjadi masalah besar, ketika yang memegang harta ini kemudian menyusul wafat. Kerancuan tentang kepemilikan harta akan sangat besar terjadi. Penundaan juga bisa terjadi tanpa ada sebab yang pasti. Hanya menunda. Perkara ini juga bisa menjadi masalah di kemudian hari, ketika diantara ahli waris yang berhak kepada harta tersebut juga menyusul wafat. Kadang-kadang, penundaan terjadi karena pemahaman mestinya menjual aset warisan secepatnya. Sehingga ketika aset warisan lambat terjual menyebabkan pembagian warisan pun menjadi ikut tertunda.

Perkara penundaan diatas bisa diatasi dan disiasati dengan baik. Dimulai dengan pemahaman yang benar, bahwa amanah (perpindangan harta) harus disampaikan kepada yang berhak $^{27}$, adalah kewajiban yang harus dijalankan. Penundaan pemberian kepada yang berhak menerimanya -pada sebab ahli waris pasangan- termasuk suatu kezhaliman.

Pemahaman yang benar inilah yang dapat menyelamatkan dari penundaan karena sebab pemahaman aset yang mesti dijual cepat. Dalam pembagian waris, yang dibagi adalah bagian ahli waris (al-furudh al-muqaddarah). 1/2, 1/4 dan seterusnya. Bukan jumlah nominal uang misalnya. Sehingga ketika diantara harta

\footnotetext{
${ }^{27}$ Lihat QS. Al-Nisa: 58
} 
warisan itu dalam bentuk aset, tidak lalu harus diuangkan. Aset warisan ini, rumah contohnya, ketika saatnya berpindah kepemilikan, yang dibagi sebagai hitungan waris dalam Islam adalah berapa bagian ahli waris dirumah tersebut. Sehingga kalau bagian itu sudah didapat, kapan saja rumah itu diuangkan, tidak akan menjadi permasalahan lagi.

Pada kasus penyamarataan bagian laki-laki dan perempuan, jalur penyelesaiannya harus dikembalikan kepada syariat. Bahwa penentuan pembagian ini, datangnya langsung dari Allah swt. Diantara keistimewaan waris ini, alfurudh al-muqaddarahnya Allah sendiri yang didetailkan di dalam ayat. Dari sini saja, bagi orang yang beriman, dapat menjadi hujjah tentang mestinya mengamalkan perintah tersebut. Disertai dengan mengungkap hikmah dan sebab dibalik pensyariatannya, seperti yang dibahas dilembaran awal pada penafsiran ayat-ayat waris.

\section{Penutup}

Sebuah kemustahilan Allah menurunkan syari'at waris kepada umat Islam tanpa adanya suatu keadaan yang melatar belakanginya. Sebagaimana syari'at lainnya, syari'at waris diturunkan untuk memberikan pengaturan bagi manusia dan memberikan rasa adil. Di antara hikmah dan tujuannya yaitu: Menghormati hak dan kewajiban yang berhubungan hak adami mayit dan ahli waris: mengurus jenazah, melaksanakan wasiat dan menyelesaikan utang piutang. Serta hak keluarga mayit yakni menerima harta warisan. Menghindari perselisihan antar ahli waris atau keluarga mayit yang ditinggalkan. Menjaga silaturahmi keluarga dari ancaman perpecahan yang disebabkan harta warisan serta memberikan rasa aman dan adil. Terjaganya harta warisan hingga sampai kepada individu yang berhak menerima harta warisan. Memberikan legalitas atas kepemilikan harta warisan dan memberikan rasa keadilan bagi semua ahli waris. Menghindarkan diri dari perselisihan dan perpecahan, bahkan pertengkaran dan pertumpahan darah akibat rebutan harta peninggalan. Memahami hukum-hukum Allah yang berkaitan dengan pembagian harta peninggalan. Sebagai estafer kebersambungan ilmu, menghindarkan kelangkaan orang yang faham dalam pembagian harta warisan. 


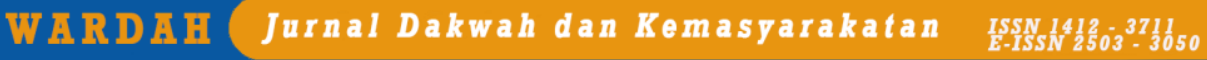

Hikmah-hikmah inilah harapannya, menjadi suntikan semangat untuk melestarikan ilmu faraidh. Menunaikan fardhu kifayah dalam proses belajar dan mengajarnya. Dan menerapkan dalam kehidupan sebagi wujud fardhu 'ain bila tiba saatnya. Dari itu, semoga ancaman yang disebut dalam rentetan ayat yang berbicara tentang waris ini:

"Dan barang siapa yang mendurhakai Allah dan Rasul-Nya dan melanggar batas-batas hukum-Nya, niscaya Allah memasukkannya ke dalam api neraka, dia kekal di dalamnya dan dia akan mendapatkan azab yang menghinakan." ${ }^{28}$ Allahul Musta'an.

\section{Daftar Pustaka}

Abdul Aziz, Faishal. (1996). Taufiq al-Rahman fi Durus al-Quran. Riyadh: Dar al-'Ashimah.

Al-Baidhawi, Nashiruddin Abu Sa'id Abdullah. (1418H). Anwar al-Tanzil wa Asraru al-Ta'wil, Beirut: Dar Ihya al-Turats al-'Arabi.

Al-Bujairimi, Sulaiman bin Muhammad bin Umar. Tanpa Tahun. Tuhfah alHabib 'ala Syarh al-Khatib, Beirut: Dar al-Fikr.

Al-Bukhari, Abu Abdillah Muhammad bin Ismail. (2004). al-Jami' al-Shahih: Kairo: Dar al-Hadits.

Al-Dimyathi, Usman bin Syata. (1997). I'anah al-Thalibin 'ala Hilli Alfazhi Fath al-Mu'in, Beirut: Dar al-Fikr.

Al-Husaini, Muhammad bin Muhammad bin Abd al-Razzaq al-Husaini. Tanpa Tahun. Taj al-'Urus min Jawahir al-Qamus. Tanpa Penerbit, Dar alHidayah.

Al-Jurjawi, Ali Ahmad. (2003). Hikmah al-Tasyri' wa Falsafatuhu Beirut: Dar alFikr.

Al-Shabuni, Muhammad Ali. (1996). Pembagian Waris Menurut Islam, ter. A.M Basalamah. Jakarta: Gema Insani Press.

(1997). Shafwah al-Tafsir. Kairo: Dar al-Shabuni.

${ }^{28}$ Lihat QS. al-Nisa: 14 
Al-Ukburi, Abu al-Baqa'. (1995). al-Lubab fi 'Ilal al-Bina wa al-I'rab, Damaskus: Dar al-Fikr.

Al-Wahidi, Ali bin Ahmad. (1969). Asbab Nuzul al-Quran, Kairo: Dar al-Kitab alJadid.

Al-Zamakhsyari, Abu al-Qasim Mahmud bin Umar bin Muhammad. (1995). alKasysyaf 'an Haqaiq Ghawamidh al-Tanzil wa 'Uyun al-Aqawil fi Wujuh al-Ta'wil, Beirut: Dar al-Kutub al-'Ilmiyyah.

Al-Zuhaily, Wahbah. (1997). al-Fiqh al-Islam wa Adillatuh. Beirut: Dar al-Fikr

Ibn Katsir, Abu al-Fida Ismail. (2010). Tafsir al-Quran al-Azhim. Kairo: Dar alHadits.

Projodikoro, Wiryono. (1983). Hukum Warisan di Indonesia, Bandung: Sumur.

Quthb, Sayyid. (1991). Fi Zhilal al-Quran. Kairo: Dar al-Syuruq.

Razzaq, A., \& Haryono, A. (2017). Analisis Metode Tafsir Muhammad AshShabuni dalam Kitab rawâiu' al-Bayân. Wardah,18(1), 48-59. https://doi.org/https://doi.org/10.19109/wardah.v18i1.1432

Razzaq, A., \& Saputra, D. (2016). Studi Analisis Komparatif Antara Ta'wil dan Hermeneutika dalam Penafsiran al-Qur'an. Wardah,17(2), 89-114. Retrieved from http://jurnal.radenfatah.ac.id/index.php/warda/article/view/961.

Rofiq, Ahmad. (2000). Hukum Islam di Indonesia. Jakarta: PT. Raja Grafindo Persada.

Summa, Muhammad Amin. (2005). Hukum Keluarga Islam di Dunia Islam. Jakarta; PT. Raja Grafindo Persada.

Thantawi, Muhammad Sayyid. (1997). al-Tafsir al-Wasith, Kairo: Dar Nahdhah.

Yunus, Mahmud. (1990). Kamus Arab-Indonesia. Jakarta: Hidakarya Agung. 